\title{
Geliat Keberagamaan Moderat Komunitas Muslim Tionghoa (Kontribusi Pengkajian Islam Intensif dalam Keberagamaan Moderat Komunitas Muslim Tionghoa Kota Makassar)
}

\author{
Rosmini, Syamsidar, Haniah \\ Fakultas Dakwah dan Komunikasi UIN Alauddin Makassar \\ mini_din@yahoo.com
}

\begin{abstract}
Studying of the Qur'an continuously, integrated and comprehensively becomes a necessity if we want to practice the teachings of Islam "kaffah". At least, this is the basis of dakwah implemented by the Chinese Muslim community in Makassar. One indicator of being "kaffah" in embracing Islam is always showing moderate religious attitudes in all aspects of life, both individual and collective, at the level of faith, worship, muamalah, and morals. In understanding and practicing the teachings of Islam, the Chinese Muslim community in Makassar reflects religious moderation; therefore, their presence did not cause conflict in Makassar locally, but a blessing for the local community. Their Chinese identity is maintained by reconstructing the religious value of their traditions and culture. In this community, the belief of Islamic theology is not religiously indicated as elements of syncretism. As a result, their Chinese identity survives copes with their Islamic belief. Ultimately, moderate of Islamic teachings, as a religion of "rahmatan lil al alamiin", is then reflected in their daily lives, including in their religious attitudes and behavior.
\end{abstract}

\begin{abstract}
Abstrak
Pengkajian Al-Qur'an secara berkesinambungan, terpadu dan komprehensif menjadi sebuah kemestian jika ingin mengamalkan ajaran Islam secara kaffah. Setidaknya hal ini yang mendasari dakwah yang diperankan oleh komunitas muslim Tionghoa Kota Makassar. Salah satu indikator kaffah dalam keberislaman seseorang adalah senantiasa menampilkan sikap keberagamaan moderat dalam segala aspek kehidupan. Dalam pemahaman dan pengamalan agama Islam, komunitas muslim Tionghoa Makassar dikesani merefleksikan moderasi beragama, sehingga keberadaannya di Makassar tidak menimbulkan gejolak lokal, melainkan menjadi berkah bagi masyarakat setempat. Identitas kecinaan mereka tetap dipertahankan dengan melakukan rekonstruksi nilai yang melatari tradisi dan kebudayaan mereka. Akidah Islam yang diyakini terbebas dari unsur sinkretisme. Etnisitas kecinaan mereka tetap survive dalam keislaman mereka. Ajaran Islam yang moderat sebagai agama rahmatan lil al-alamiin kemudian direfleksikan dalam kehidupan keseharian mereka, termasuk dalam sikap dan perilaku keberagamaan mereka.
\end{abstract}

Keywords: Keberagamaan, Moderat, rekonstruksi, tradisi \& budaya 


\section{A. Pendahuluan}

Upaya kontekstualisasi pemahaman umat terhadap Islam merupakan suatu kemestian karena Al-Qur'an diturunkan oleh Allah dengan mempertimbangkan realitas masyarakat. Hukum-hukum agama tidak disyariatkan dengan sia-sia dan hampa makna, melainkan Allah meletakkan kemaslahatan sebagai fondasi dan filosofi penetapan hukumhukum itu. ${ }^{1}$ Hal ini sebagaimana telah dikemukakan oleh al-Syathibi sebelumnya bahwa perbuatan-perbuatan hukum tidak diadakan dengan sendirinya, namun melekat padanya tujuan-tujuan perbuatan itu. Taklif dalam syariat tidak mungkin bertentangan dengan rasionalitas manusia. ${ }^{2}$

Doktrin al-Islam shalih li kulli zaman waa makan kemudian menstimulasi upaya adaptasi yang dimaksud meskipun berpotensi melahirkan perbedaan pendapat. Hal ini sebagai akibat perbedaan dalam memaknai doktrin Islam yang termaktub dalam Al-Qur'an dan hadi-hadis Nabi yang kemudian berimplikasi terhadap polarisasi sikap keberagamaan umat Islam. Pada satu kutub, dikenal praktek-praktek keberislaman yang bercorak fundamental, ortodoks, otentik dan puritan di kalangan umat Islam sendiri. Konsep pemikiran keaagamaan yang dibangun oleh kelompok ini disandarkan kepada metode penafsiran teks-teks wahyu dan hadis dengan rigid serta kurang bijaksana membaca realitas sosial. Ciri khas pemikiran mereka senantiasa menuntut ketegasan dalam menafsirkan teks. ${ }^{3}$ Di kutub yang berbeda, terdapat kelompok memahami Al-Qur'an sesuai dengan locus teks dan menafsirkannya secara kontekstual sehingga mampu menjawab masalah-masalah kemanusiaan yang semakin kompleks di era modern. Mengadapsikan Al-Qur'an dengan fenomena modernitas yang sangat plural menjadi orientasi pengkajian teks kelompok ini. Penempatan rasio di atas wahyu menjadikan Islam kehilangan sakralitas Kitab Sucinya karena senantiasa ditarik untuk menyesuaikan diri dengan rasionalitas. Umumnya, kelompok ini sering disebut dengan Islam liberal, Islam substantif, dan Islam aktual.

\footnotetext{
${ }^{1} \mathrm{Sa}$ 'du al-Din al-Usmani, Tasarrufat al-Rasul bi al-Imamah : al-Dalalat al-Manhajiyyah wa al-Tasyri'iyyah, Abd. Rauf Amin (terj.), Kontekstualisasi Hadis : Menguak Muatan Hukum dan Metodologi dari Realitas Sunnah Nabi (Cet. I; Makassar: Alauddin University Press, 2011), h. 18.

${ }^{2}$ Al-Syathibi, al-Muwafaqat fi Ushul al-Fiqhi, Jilid IV (Beirut: Dar al-Ma'rifah), h. 95.

${ }^{3}$ Khaled Abou al-Fadl, The Great Theft : Wrestling Islam From The Extremists (America: Perfect Bound HarperCollins Publishers, 2005), h. 19.
} 
Salah satu kelompok masyarakat yang dikenal memiliki dan merefleksikan paham keagamaan dan sikap keberagamaan moderat di Indonesia yaitu komunitas muslim Tionghoa. Moderasi keberagamaan yang ditampilkan oleh muslim Tionghoa tidak lepas dari kuatnya ikatan tradisi dalam kehidupan mereka. Tradisi dan religiusitas dalam kehidupan orang Cina adalah dua hal yang tak terpisahkan, tak terkecuali bagi muslim Tionghoa atau orang Cina yang telah melakukan konversi agama dari agama non-Islam ke agama Islam. ${ }^{4}$ Seseorang bisa menjadi Tionghoa sekaligus menjadi muslim sehingga kategorisasinya bercampur menjadi muslim Tionghoa. ${ }^{5}$

Dalam perspektif sikap keberagamaan atau keberislaman, langkah ini dipahami sebagai bagian dari model sikap keberagaman moderat, suatu sikap keberagamaan yang tetap mempertahankan nilai-nilai tauhid dan syariat tanpa meninggalkan nilai budaya atau nilai lokalitas yang dimiliki. Akomodasi terhadap tradisi meskipun telah berkonversi ke agama Islam juga dipraktekkan oleh komunitas muslim Tionghoa Makassar. Meskipun beberapa tradisi kecinaan pada awalnya sarat dengan nilai-nilai mitos dan nilai ritual yang cenderung politeistik (syirik), namun muslim Tionghoa Makassar tetap melaksanakannya dengan melakukan sejumlah rekonstruksi nilai di dalamnya. Dengan performa keberagamaan seperti ini, komunitas muslim Tionghoa mengklaim menampilkan model keberagamaan yang tidak ekstrem atau moderat. Yakni sebuah pola keberagamaan yang mencoba secara konsisten mengamalkan nilai-nilai ajaran Islam yang tertuang dalam Al-Qur'an dan hadis namun tetap berupaya melakukan penyelarasan terhadap tradisi etnisitas. ${ }^{6}$

Dalam mempertahankan dan mensosialisasikan model keberagamaan moderat, komunitas ini sangat intens dalam melakukan pembinaan umat secara internal. Salah satu usaha konkret dalam mengimplementasikan hal ini adalah dengan melakukan pengkajian Islam secara terarah dan terstruktur agar mereka dapat menjalankan syariat agama yang mereka yakini tanpa harus melepaskan identitas kecinaannya

\footnotetext{
${ }^{4}$ Afthonul Afif, Menjadi Indonesia: Pergulatan Identitas Tionghoa Muslim Indonesia (Yogyakarta: Parikesit Institute, 2010), h. 167.

${ }^{5}$ Samsul Huda, "Orang Indonesia Tionghoa dan Persoalan Identitas", dalam Kontekstualita, Vol. 25, No. 1, 2010, h. 165-166.

${ }^{6}$ A. Zaenurrafik, China Naga Raksasa Asia:Rahasia Sukses China Menguasai Dunia (Cet. I; Yogyakarta: GARASI, 2008),h. 67. Lihat juga Abbas Mahmud Akkas, Ketuhanan Sepanjang Ajaran Agama-Agama (Jakarta: Bulan Bintang, 1973), h. 71.
} 
di tengah pluralitas masyarakat Kota Makassar. Oleh sebab itu, penelitian ini akan mengurai dua masalah beikut: pertama, bagaimana model pengkajian Islam yang dilaksanakan oleh komunitas muslim Tionghoa Kota Makassar? Kedua, bagaimana kontribusi pengkajian Al-Qur'an secara intensif dalam membentuk keberagamaan moderat muslim Tionghoa Kota Makassar?

Penelitian ini merupakan penelitian kualitatif deskriptif, metodologi kualitatif merupakan prosedur penelitian yang menghasilkan data deskriptif berupa kata-kata tertulis maupun lisan dari orang-orang dan perilaku yang diamati. ${ }^{7}$ Dari sisi keilmuan akademik, pendekatan penelitian yang digunakan dalam penelitian ini adalah pendekatan normatif Islam yaitu dengan menjadikan al-Qur'an dan hadis Nabi sebagai tolok ukur dalam mendiskusikan moderasi keberagamaan muslim Tionghoa Kota Makassar. Selain itu, pendekatan lain juga digunakan. Di antaranya pendekatan psikologi agama dan antropologi agama.

Adapun teknik penentuan informan dalam penelitian ini adalah teknik purposive sampling yaitu suatu teknik penentuan informan penelitian berdasarkan tujuan penelitian yang telah ditetapkan sebelumnya. Berdasarkan teknik ini, maka informan yang dijadikan sumber data penelitian ini adalah individu muslim Tionghoa yang kehadirannya pada kegiatan pengkajian Al-Qur'an termasuk kategori tinggi (sering). Adapaun instrumen yang digunakan dalam penelitian ini Human instrument (peneliti sebagai instrumen). Selain itu, pedoman FGD (Focus Group Discussion) berupa pertanyaan-pertanyaan kunci terkait dengan model pengkajian Islam intensif dan kontribusinya dalam keberagamaan moderat komunitas muslim Tionghoa Kota Makassar. Pedoman wawancara (interview guide), dan Pedoman observasi. Adapun analisis data dalam penelitian ini dilakukan secara kualitatif dan disesuaikan dengan fokus masalah yang diteliti dengan tahapan (a) Klasifikasi data; (b) Reduksi data; (c) Penyajian data; (d) Konklusi dan verifikasi; tahapan akhir (e) analisis data. ${ }^{8}$

\section{B. Terminologi Moderasi Beragama dalam Al-Qur'an}

Kata moderat berasal dari bahasa Inggris moderate yang berarti mengambil sikap tengah, yakni tidak berlebih-lebihan pada satu posisi

\footnotetext{
${ }^{7}$ Lexy. J. Moleong, Metode Penelitia Kualitatif (Bandung: Rosdakarya, 2001), h. 3

${ }^{8}$ Sugiyono, Metode Penelitian Pendidikan : Pendekatan Kuantitatif, Kualitatif, dan $R$ \& $D$ (Cet. XXII; Bandung: Alfabeta, 2015), h. 337-338.
} 
tertentu, ia berada pada titik sikap yang tegak lurus dengan kebenaran. Moderator seorang penengah yang mampu menyatukan dua kubu persoalan secara seimbang dan harmonis, dengan tanpa mengorbankan nilai-nilai kebenaran. ${ }^{9}$ Moderasi beragama dalam Al-Qur'an dapat dirujuk kepada وسطا(QS al-Baqarah:2/143). Menurut Al-Ashfahani, wasath berarti titik tengah, seimbang, tidak terlalu ke kanan (ifrath) dan tidak terlalu ke kiri (tafrith), di dalamnya terkandung makna keadilan,keistiqamahan, kebaikan, keamanan dan kekuatan. ${ }^{10}$

Selain term wasath, moderasi dalam Al-Qur'an juga diungkapkan dengan term استقامة(QS Hud/11:112). Dalam Tafsir al-Mishbah ${ }^{11}$ ditemukan penafsiran ayat ini bahwa استقم terambil dari kata قام yang berarti mantap, terlaksana, berkonsentrasi serta konsisten. Istaqim adalah perintah untuk menegakkan sesuatu sehingga ia menjadi sempurna, dan semua yang diharapkan darinya terwujud dalam bentuk yang sesempurna mungkin, tidak disentuh oleh kekurangan atau keburukan dan kesalahan. al-Qurtubi mengomentari bahwa istiqamah dimaknai dengan sikap yang terus-menerus berada pada satu sisi (jalan lurus) tanpa condong ke kanan ataupun ke kiri. Perintah istiqamah dalam hal ini terus-menerus melaksanakan perintah Allah. ${ }^{12}$

Yusuf Qardhawi menjelaskan bahwa di antara bentuk moderasi beragama adalah (1) mengerjakan yang ma'ruf dan melarang yang mungkar; (2) menghalalkan yang halal (QS al-Maidah/5:87; QS alAn'am/6:119; QS Thaha/20:81; QS al-Tahrim/66:1) dan mengharamkan yang haram (QS al-A'raf/7:157); (3) tidak mewajibkan atau membebankan sesuatu yang tidak diwajibkan atau dibebankan Allah (QS al-A'raf/7:157); (4) tidak memaksakan orang lain mengerjakan hal-hal yang sunnah dengan menganggapnya seolah-olah wajib dan menganggap yang makruh seolaholah haram; (5) tidak memperberat sesuatu yang bukan pada tempat dan zamannya (QS al-Baqarah/2:185; QS al-Insyirah/94: 5-6; QS alThalaq/65: 4, 7; QS al-Dukhan/44: 58; QS Maryam/19: 97; QS al-

\footnotetext{
${ }^{9}$ John M. Echols dan Hasan Shadili, Kamus Inggris Indonesia (Jakarta: Gramedia, 2003), h. 384.

${ }^{10}$ Al-Raghib al-Ashfahani, Mufradat Alfazh Al-Qur'an (Beirut: al-Dar al-Syamiyah, 1992), h. 869.

${ }^{11}$ M. Quraish Shihab, Tafsir al-Mishbah : Pesan, Kesan, dan Keserasian Al-Qur'an (Cet. VI; Jakarta: Lentera Hati, 2006), 258-362.

${ }^{12}$ al-Qurtuby, al-Jami' li Ahkam Al-Qur'an, Juz XI, (Cet. I; Beirut-Libanon: Muassasah al-Risalah, 2006), h.224.
} 
Kahfi/18: 88 ); (6) bersikap lunak dan lemah lembut dalam berkomunikasi dan berdakwah (QS Ali-Imran/3: 159, QS al-Isra'/17: 125), bertentangan dengan petunjuk Allah dan Rasul-Nya; (6) tidak berburuk sangka terhadap orang lain (QS al-Hujurat/49:12); (7) menghindari terjerumus dalam pengkafiran orang lain; (8) tidak fanatik yang berlebihan terhadap pendapat sendiri dengan menyalahkan pendapat orang lain. ${ }^{13}$

\section{Islam sebagai Ajaran Moderat}

Moderasi akidah Islam menentang ekstremisme akidah agamaagama lain, termasuk akidah Yahudi dan Nasrani. Di antara bentuk ekstremisme akidah Yahudi yang dikemukakan dalam Al-Qur'an adalah akidah mereka yang mempersekutukan Allah swt. dengan yang lain, termasuk penyembahan mereka terhadap sapi (QS al-Baqarah/2:51 dan QS al-A'raf/7:148), ${ }^{14}$ Yahudi menyifatkan Allah swt. dengan sifat kefakiran sebagaimana dalam QS al-Imran/3:81, menyifatkan Allah swt. dengan tangan yang terbelenggu sebagaimana dalam QS al-Maidah/4:64. Yahudi juga mempersamakan Allah Swt. dengan makhluk-Nya dengan meyakini bahwa Allah Swt. memiliki anak sebagaimana dalam QS al-Taubah/9:30. Jika Yahudi menarik posisi Tuhan ke posisi makhluk, maka Nasrani mendorong posisi makhluk ke posisi Tuhan. ${ }^{15}$

Moderasi akidah Islam juga dapat dilihat dari ajaran Islam tentang sistem keyakinan kepada hal-hal yang gaib atau abstrak. Eksistensi metafisik ditegaskan dalam Islam dalam jangkauan dalil yang bisa dipertanggunjawabkan baik secara naqli dan secara aqli. ${ }^{16}$ Ibadah ritual dalam Islam tidak hanya berdimensi vertikal, namun juga berdimensi horizontal. Artinya, pelaksanaan ibadah ritual seyogyanya memiliki nilai fungsional dalam kehidupan sehari-hari seorang muslim. Dengan kata lain, ritualitas itu diadakan untuk memenuhi dua jenis kebutuhan manusia, yaitu spiritualitas dan materialitas. Di sinilah letak moderasi ajaran-ajaran ritual Islam.

\footnotetext{
${ }^{13}$ Yusuf Qardhawi, al-Shahwah al-Islamiyyah Bayn al-Juhud wa al-Tatharruf (Cet. I; Kairo: Dar al-Syuruq, 2001),h. 35-48.

14 'Ali Muhammad al-Syalabi, Wasathiyyat Al-Qur'an fi al-'Aqa'id : Arkan al-iman alSittah (Iskandariyyah: Dar al-Iman, t.th), h. 36.

${ }^{15}$ Rosmini, Ekstremisme Keberagamaan Perspektif Al-Qur'an, Disertasi (Pascasarjana Universitas Islam Negeri Alauddin Makassar, 2015), h. 182-184.

${ }^{16} \mathrm{Abu}$ Yasid, Islam Moderat, h. 53.
} 
Moderasi (keseimbangan) ajaran Islam tidak hanya terefleksi dalam ajaran akidah dan ritual, melainkan juga dipantulkan melalui ajaran moral atau akhlak Islam. Hablumminallah dan hablumminnas adalah dua poros ibadah Islam yang tidak dapat dipisahkan satu sama lain jika seorang muslim berjuang menggapai posisi takwa di sisi Allah. Islam adalah agama pertengahan, termasuk dalam hal ekonomi. Hassan Hanafi menggambarkan kapitalisme sebagai kediktatoran dan dominasi yang selalu bersekutu dengan feodalisme dan imprealisme. ${ }^{17}$ Di poros yang berseberangan, ekonomi sosialisme muncul sebagai antitesa ekonomi kapitalisme. Jika kapitalisme memberikan kebebasan tak terbatas untuk memiliki harta kekayaan, maka sosioalisme justru menghilangkan kebebasan. Moderasi prinsip ekonomi Islam dapat menjembatani prinsip individualisme yang melandasi ekonomi kapitalisme dan prinsip kolektivisme yang melandasi ekonomi sosialisme. Kapitalisme mengakui hak individu dalam melakukan aktivitas ekonomi secara bebas tanpa batas, baik dalam hal produksi maupun distribusi. Paham kapitalisme ini secara jelas dicela dalam Al-Qur'an (QS al-Qalam/68:17-33). Ajaran Al-Qur'an tentang infak dalam bentuk zakat dan sedekah merupakan ajaran yang menentang sistem kapitalisme. Zakat mengecilkan gap antara orang kaya dan orang miskin, sehingga tidak ada orang yang merasakan kekurangan. Sedekah harus didasarkan pada kerelaan hati dalam mengeluarkannya. Dengan kata lain, Islam tidak hanya memprioristaskan pertumbuhan dan peningkatan ekonomi, tapi juga memerintahkan pemerataan ekonomi yang melahirkan kesejahteraan bersama.

\section{Peran PITI Dalam Pembinaan Muslim Tionghoa Kota Makassar}

Persatuan Islam Tionghoa Indonesia (PITI) merupakan salah satu organisasi masyarakat yang dimiliki oleh etnis Tionghoa. PITI Makassar adalah cabang dari PITI pusat yang berada di Jakarta. PITI merupakan organisasi hasil peleburan dari dua organisasi yaitu Persatuan Islam Tionghoa (PIT) dan Persatuan Tionghoa Muslim (PTM). Organisasi ini didirikan jauh sebelum reformasi yaitu pada tanggal 14 Mei 1961. Sedangkan PITI Makassar dibentuk pada tahun 1992. Kegiatan prioritas organisasi ini adalah kegiatan yang berorientasi dakwah dan syiar Islam. Selain melakukan pengkajian Islam dan pengajian Al-Qur'an serta kegiatan-kegiatan ibadah di berbagai tempat, organisasi ini juga

${ }^{17}$ A.H. Ridwan, Reformasi intelektual Islam : Pemikiran Hassan Hanafi tentang Reaktualisasi Tradisi Keilmuan Islam (Yogyakarta: ITTAQA Press, 1998), h. 81. 
melakukan aktivitas sosial dengan mengunjungi panti asuhan dan berbagai wilayah-wilayah orang yang kurang mampu secara ekonomi (dhuafa).

Pengajian Al-Qur'an dan pengkajian Islam di kalangan muslim Tionghoa Makassar telah dimulai jauh sebelum terbentuknya organisasi PITI di Kota Makassar dan masih berlangsung sampai sekarang. Bahkan pengajian ini juga pernah dilakukan secara berkala oleh organisasi Generasi Muda Tionghoa Islam Indonesia (GMTII) ${ }^{18}$ yang kemudian membaur dalam keanggotaan PITI. Hal ini menunjukkan bahwa betapa signifikannya posisi kegiatan pengkajian dan pendalaman Islam secara berkesinambungan dalam menuntun keberislaman etnis Tionghoa muslim.

Satu hal yang dapat membuktikan posisi sentral PITI sebagai inisiator dan fasilitator dalam pembinaan keagamaan muslim Tionghoa khususnya dalam kegiatan pengkajian Islam intensif komunitas Tionghoa adalah adanya acara penyampaian "Kata Sambutan" dari pengurus PITI sebagai rangkaian acara pengkajian Islam setiap kali kegiatan itu mulai dilaksanakan. Penyampaian "Kata Sambutan" tidak hanya didengar pada acara pengkajian Islam Intensif, namun hal itu juga ditemukan dalam rangkaian acara-acara keagamaan lainnya, misalnya kegiatan dzikir bersama setiap jum'at, dzikir bersama menjelang tahun baru masehi. Selain itu, "Kata Sambutan" dari pengurus PITI juga ada dalam rangkaian acara peringatan hari-hari besar Islam, misalnya acara Maulid Nabi saw., acara Isra' Mi'raj, dan juga halal bi halal seusai pelaksanaan hari raya Idul Fitri. Fakta di atas sekaligus menegaskan bahwa sikap keberagamaan dan tanggung jawab keorganisasian pimpinan organisasi PITI sangat berpengaruh terhadap kesinambungan kegiatan dakwah Islam khususnya pengkajian Islam Intensi

\section{E. Model Pengkajian Islam Komunitas Muslim Tionghoa Kota Makassar}

a. Tujuan

1) Pembinaan Pemahaman Keagamaan Anggota PITI secara Internal.

Etnis Tionghoa yang bergabung di PITI kebanyakan dari mereka yang muallaf, yakni mereka yang tidak lahir dari keluarga muslim dan menyatakan diri masuk Islam atas kesadaran sendiri di umur anak, remaja,

\footnotetext{
${ }^{18}$ Aminuddin Ramli, Alih Agama di Kalangan Etnik Tionghoa : Studi Kasus Muallaf Tionghoa di Makassar, Disertasi (Makassar: program Pascasarjana Universitas Hasanuddin Makassar, 2009), h. 143.
} 
dewasa ataupun setelah menjadi orang tua. Selain itu, ada juga etnis Tionghoa bergabung di keanggotaan PITI dan aktif mengikuti pengkajian Islam dari mereka yang lahir dalam keadaan Islam karena sebelumnya orangtua mereka telah menyatakan diri memeluk Islam. Di pengkajian Islam ini, para peserta baik yang muallaf maupun yang bukan muallaf memiliki kesempatan yang sama untuk berinteraksi secara dialogis dengan narasumber, baik terkait dengan materi secara langsung maupun di luar konteks materi namun masih terkait dengan pemahaman keislaman.

2) Mempererat Silaturrahmi antara Muslim Tionghoa dan Muslim non Tionghoa

Sebagaimana telah dipaparkan sebelumnya bahwa peserta atau jamaah yang hadir dalam kegiatan pengkajian Islam tidak hanya terdiri dari muallaf Tionghoa, namun juga dihadiri oleh muslim non Tionghoa, terutama yang memiliki hubungan keluarga akibat perkawinan atau persahabatan dengan salah seorang warga Tionghoa. Sebagai orang yang pernah memeluk agama selain Islam, para muallaf Tionghoa membutuhkan dukungan moril untuk mempertahankan komitmen keberislamannya, baik di lingkungan keluarga besarnya maupun di lingkungan etnis Tionghoa sendiri yang belum meyakini kebenaran Islam. Bahkan, dukungan sesama muslim non Tionghoa akan sangat membantu muallaf Tionghoa untuk bersosialisasi dengan penganut agama lain dalam interaksi sosialnya dalam konteks yang lebih luas lagi.

Satu hal yang mendesak untuk dipertimbangkan secara serius oleh ormas PITI bahwa pengkajian Islam sebaiknya tidak hanya ditujukan kepada komunitas muallaf orang tua, akan tetapi mengupayakan adanya pengkajian Islam yang ditujukan kepada anak-anak dan remaja. Hal ini dilakukan agar supaya pembinaan terhadap muallaf diselenggarakan secara komprehensif sehingga dapat mengantisipasi perkembangan keberagamaan generasi muda muallaf Tionghoa di masa sekarang dan di masa akan datang. ${ }^{19}$

3) Sosialisasi Eksistensi Muslim Tionghoa di Tengah Masyarakat Muslim

Sebagai komunitas muslim yang berbasis etnis yang ditandai dengan keberadaan organisasisi PITI, komunitas muslim Tionghoa memiliki identitas tersendiri yang membedakannya dari organisasi

${ }^{19}$ KH. Yahya Tan, Pembina Ormas PITI Sulawesi-Selatan, Wawancara, 06 Nopember 2015. 
masyarakat Islam lainnya. Salah satu ciri identitas yang dimaksud adalah komunitas ini terdiri dari banyak muallaf baik dari kalangan warga Tionghoa sendiri maupun dari muallaf nonTionghoa meskipun yang terakhir ini jumlahnya terbatas. Sebagai komunitas muallaf, komunitas ini memiliki warisan tradisi keagamaan dari agama sebelumnya yang berkolaborasi dengan tradisi etnisitas, etnis Tionghoa yang terkesan politeistik. Kedua tradisi ini kemudian mengalami penyesuaianpenyesuaian prinsipil agar tidak mengganggu dimensi substansial agama yang baru mereka terima yakni agama Islam.

4) Mempertegas Identitas dan Eksistensi Muslim Tionghoa di Kalangan Tionghoa Non Muslim

Salah satu pencitraan Tionghoa totok yang telah menyejarah dalam sejarah perjuangan bangsa Indonesia merdeka dari penjajahan bahwa Islam itu agama pribumi dan pribumi itu adalah pihak yang terjajah. Sehingga mereka yang memeluk Islam dianggapnya sebagai penduduk Indonesia kelas sekunder. Sebagai pihak sekunder umat Islam kemudian ditempatkan pada posisi yang tidak dperhitungkan keberadaannya karena tidak memiliki nilai tawar yang unggul dalam keseluruhan dimensi penyelenggaraan kehidupan berbangsa dan bernegara. Persepsi ini bagi sebahagian etnis Tionghoa totok di Makassar masih dianut dan relatif berpengaruh terhadap pola interaksi etnis Tionghoa dengan umat Islam pada umumnya. ${ }^{20}$

Kegiatan pengkajian Islam yang diselenggarakan secara berkesinambungan diharapkan dapat merubah persepsi di atas dan pada gilirannya akan mempertegas identitas dan eksistensi muslim Tionghoa di kalangan Tionghoa non muslim. Penegasan identitas dalam konteks ini sangat diperlukan mengingat bahwa etnis Tionghoa di Kota Makassar memiliki banyak organisasi masyarakat baik yang berbasis etnis Tionghoa maupun yang berbasis agama selain Islam. Dalam konteks ini program unggulan PITI berupa pengkajian Islam intensif menjadi penegasan akan eksistensi PITI sebagai representasi dari eksistensi Tionghoa muslim.

Meskipun penjadwalan telah dilakukan secara serius, namun materi yang disuguhkan tidak disusun secara hirarkis sesuai dengan kebutuhan keilmuan Islam dasar seorang muallaf. Salah seorang pembina komunitas muslim Tionghoa yang bernaung di PITI mengemukakan bahwa pengkajian Islam semestinya dilakukan secara berjenjang mulai

\footnotetext{
${ }^{20}$ H. John Adam, Ketua DPW PITI Sulawesi Selatan, Wawancara, Oktober 2015.
} 
dari tingkat dasar sampai seterusnya. Perjenjangan tersebut bertujuan untuk memberikan pengetahuan keislaman secara mendasar kepada muallaf termasuk pengetahuan tentang ritualitas Islam secara praktis. Hal ini dilakukan karena bagi seorang muallaf keyakinan akan kebenaran telah dipahami dengan baik ketika mengambil keputusan untuk berkonversi ke Islam. Sehingga pengkajian Islam yang dilakukan tidak sebaiknya didominasi oleh penyampaian materi yang berorientasi kepada hal-hal teologis dan akhlak Islam semata, melainkan penyampaian materi tentang ibadah-ibadah ritual secara praktis juga penting untuk diberikan secara internsif dan sistematis. $^{21}$

\section{F. Kontribusi Pengkajian Islam Intensif dalam Keberagamaan Moderat Komunitas Muslim Tionghoa Kota Makassar}

\section{a. Moderasi Keberagamaan Muslim Tionghoa dalam Aspek akidah}

Hasil penelitian yang dilakukan oleh M. Darwis mengungkapkan bahwa sebagian besar keturunan Tionghoa di Kota Makassar menganut agama Budha, Kristen dan sebagian kecil beragama Islam. Kepercayaan ini telah mengakar dalam keberagamaan keturunan Tionghoa karena terkait dengan ikatan kekeluargaan, yaitu hubungan orangtua dan anak yang berimplikasi kepada kewajiban anak berbakti kepada orangtua yang diwujudkan dalam konsep pengabdian kepada leluhur. ${ }^{22}$ Mereka masih percaya bahwa arwah leluhur itu dapat mendatangkan keberkahan kepada anak cucunya, sehingga pada saat-saat tertentu para leluhur mereka masih harus dipuja dan diberi sesajian sebagai bentuk penghormatan kepada leluhur. ${ }^{23}$. Tatacara mendoakan leluhur dilakukan dengan tradisi Konghucu ataupun tradisi Islam. ${ }^{24}$

Fenomena keberagamaan sinkretik di atas tidak ditemukan dalam fenomena keberagamaan muslim Tionghoa yang secara berkesinambungan mengikuti pendalaman keislaman melalui kegiatan

\footnotetext{
${ }^{21}$ KH. Yahya Tan, Pembina PITI Sulawesi Selatan, Wawancara, Jum'at, 06 Nopember 2015.

${ }^{22}$ M. Darwis, Harmoni dan Disharmoni Sosial Etnis di Perkotaan : Studi Pola Interaksi Sosial Etnik Keturunan Tionghoa dengan Etnik Makassar di Kota Makassar, Disertasi (Makassar, Program Pascasarjana Universitas Hasanuddin Makassar, 2007), h. 138.

${ }^{23}$ Shaifuddin Bahrum,Cina Peranakan Makassar:Pembauran Melalui Perkawinan Antar Budaya, h. 94.

${ }^{24}$ Shaifuddin Bahrum,Cina Peranakan Makassar:Pembauran Melalui Perkawinan Antar Budaya, h. 91.
} 
pengkajian Islam intensif secara mingguan yang diinisiasi dan dikordinasi oleh PITI. Hal ini karena program kegiatan tersebut berkonsentrasi kepada indoktrinasi akidah Islam berdasarkan dalil-dalil agama yang mu'tabar. ${ }^{25}$ Setelah mereka memeluk Islam, secara bertahap menjaga jarak dengan kepercayaan sebelumnya, meskipun keluarga besar menentang sikap tersebut. Seiring dengan proses pembelajaran dan pendalaman akidah Islam yang dijalani muallaf Tionghoa secara continous, maka hal-hal yang dapat menjerumuskan akidah Islam mereka telah dipahami dengan baik. ${ }^{26}$ Apalagi muallaf Tionghoa yang aktif dalam pengajian dan pengkajian Islam secara intensif, pemahaman akidah mereka cukup terproteksi dari berbagai virus kepercayaan politeistik.

\section{b. Moderasi Keberagamaan Muslim Tionghoa dalam Aspek Ibadah Ritual}

Berbeda dengan keseriusan muslim Tionghoa membenahi akidah, dalam hal pelaksanaan ibadah ritual Islam nampaknya tidak mendapat porsi keseriusan yang seimbang. Hal ini misalnya dapat dilihat dari feneomena keseriusan mereka memahami isi Al-Qur'an tidak sebanding dengan keseriusan memperbaiki bacaan Al-Qur'an itu sendiri. Beberapa di antara muslim Tionghoa mencukupkan diri dengan hanya membaca terjemah Al-Qur'an saja dan kurang berkonsentrasi terhadap bagaimana melafalkan Al-Qur'an dengan baik dan benar. ${ }^{27}$ Dengan kata lain. pengamalan ajaran ritual Islam tidak dibarengi dengan pemahaman mendalam terhadap subtansi ritualitas Islam yang dimaksud.

\section{c. Moderasi Keberagamaan Muslim Tionghoa dalam Aspek Etika Sosial}

Sebagaimana dipahami bahwa agama asli warga Tionghoa adalah agama Konghucu yang ajarannya terpusat pada nilai-nilai etika atau nilainilai kebajikan. ${ }^{28}$ Kebajikan yang dipahami warga Tionghoa adalah kebajikan yang berorientasi kemanusiaan karena watak perikemanusiaan itu alami atau kodrati. Sedangkan kebajikan yang dipahami muslim Tionghoa adalah kebajikan yang tidak hanya merupakan keharusan

\footnotetext{
${ }^{25}$ Informan muslim Tionghoa, Focus Group Discussian, 18 September 2015.

${ }^{26}$ Informan FGD (Focus Group Discussion), tanggal 18 September 2015.

${ }^{27}$ Elsye Natsir, Muslimah Tionghoa Makassar, Wawancara, 13 November 2015 di Makassar.

${ }^{28}$ Lasiyo, "Etika Menurut Ajaran Confusius", dalam Basis Edisi Juli 1988, h. 252.
} 
kemanusiaan, namun lebih dari itu bahwa kebajikan yang dilakukan merupakan implementasi dari penghambaan diri kepada Allah. di mana segala perbuatan manusia akan dibalas dan dipertanggunjawabkan di akhirat kelak. ${ }^{29}$

Dalam konteks keberagamaan muslim Tionghoa di Makassar, etika sosial tidak dapat dipisahkan dari etika beragama. Hal ini misalnya dibuktikan dari kesiapan para anggota kegiatan pengkajian Islam untuk secara bergantian berkontribusi dalam pembiayaan kegiatan. ${ }^{30}$ Demikian pula, kesiapan mereka berkorban secara finansial atas pembangunan dua mesjid Cheng Hoo yang terbilang mewah di Wilayah Makassar dan Gowa menjadi indikator lain integrasi etika sosial muslim Tionghoa dengan etika Islam.

\section{d. Moderasi Keberagamaan dalam Aspek Tradisi dan Budaya}

Kebudayaan merupakan suatu sumber kebajikan, sehingga kebudayaan sering kali tidak bisa dilepaskan dari agama. ${ }^{31}$ Etnis Tionghoa dikenal sebagai etnis yang sangat kuat memegang dan mempertahankan tradisi dan budaya leluhur. Ketika etnis Tionghoa konversi ke Islam, maka tradisi dan budaya yang mereka kenal dan sering lakukan sebelumnya tetap dilanggengkan dengan merekonstruksi nilai-nilai yang melatari tradisi dan budaya itu. Hal ini dilakukan agar identitas kecinaan tetap dipertahankan tanpa bersinggungan dengan nilai-nilai akidah Islam.

Di antara tradisi yang dimiliki oleh etnis Tionghoa adalah perayaan Hari Ceng Beng/Cing Ming, yang adalah suatu hari ziarah kubur tahunan bagi warga Tionghoa. Pada hari Ceng Beng ini, yang jatuh pada tanggal 5 April untuk setiap tahunnya atau tanggal 15 bulan 7 Imlek. Bagi warga muslim Tionghoa yang masih melakukan tradisi Ceng Beng atau Cing Ming, ziarah kubur dianggap sebagai ajang bersilaturrahim dengan keluarga besar sekaligus sebagai wahana untuk melakukan dakwah Islam meskipun dakwah itu terbatas dalam bentuk dakwah bil hal, dakwah dengan menampilkan perilaku-perilaku baik. Tradisi Ceng Beng dilakukan oleh warga muslim Tionghoa dengan melepaskan mitos dan praktek ritualitas yang bertentangan dengan akidah Islam. Misalnya,

${ }^{29}$ Febri Yenna Tan (Muslimah Tionghoa Makassar), Wawancara, 17 Oktober 2015 di Makassar.

${ }^{30}$ Thung Siu Ing (Mantang T), Muslimah Tionghoa Makassar, Wawancara, 26 Oktober 2015.

${ }^{31}$ K. Bertens, Etika (Jakarta: Gramedia Pustaka Utama, 2004), hlm. 29-30. 
penghormatan leluhur dengan melakukan sembahyang di rumahnya sendiri sambil meletakkan foto leluhur dan berdoa juga tidak dilakukan lagi oleh warga muslim Tionghoa. Begitupun juga, ziarah kubur tidak lagi dibatasi pada waktu tertentu sebagaimana dalam tradisi Ceng Beng itu sendiri, namun menziarahi kubur dilakukan kapan saja sebagaimana disyariatkan dalam Islam. ${ }^{32}$

Selain tradiri Ceng Beng, perayaan Hari raya Imlek juga merupakan salah satu tradiri Tionghoa yang masih dilakukan oleh muslim Tionghoa Makassar. Imlek biasanya jatuh pada bulan kedua tarikh masehi, yaitu pada bulan Februari. Bagi umat Konghucu di Indonesia melakukan sembahyang sujud syukur pada malam tahun baru Imlek merupakan pelaksanaan ibadah sesuai dengan keyakinan agamanya. Sembahyang ini mengandung makna agamis yang mendalam bagi umat Khonghucu. ${ }^{33} \mathrm{Di}$ antara informan penelitian ini ada yang mengaku bahwa pada awalnya ketika menyatakan masuk Islam dengan alasan perkawinan, masih biasa melakukan sembahyang di Kelenteng atau rumah abu sebagai pemujaan terhadap leluhur. Namun, setelah memahami Islam, pemujaan tersebut tidak dilakukan lagi karena diyakini bertentangan dengan kemurnian akidah Islam. ${ }^{34}$ Namun tradisi di atas lebih diposisikan sebagai momentum untuk berkumpul bersama keluarga besar yang kadang-kadang terdiri dari penganut agama yang berbeda. Banyak di antara warga Tionghoa yang masuk Islam masih tinggal bersama keluarga besarnya dalam satu lingkungan kecil bahkan dalam satu rumah yang memiliki agama yang heterogen. Fakta ini tentu membutuhkan penyesuaian-penyesuaian diri seorang muslim sehingga tidak menjadikan keberislamannya menjadi penyebab terjadinya keretakan hubungan silaturrahim dengan keluarga besarnya. Itu juga sebabnya, sikap keberagamaan pluralistik dalam keberislaman sebahagian muslim Tionghoa tidak bisa dihindari. ${ }^{35}$ Terkadang satu keluarga yang berbeda agama berkumpul bersama keluarga di hari raya Idul Fitri atau Idul Adha (Islam), di hari natal mereka

\footnotetext{
${ }^{32}$ Jacky Suliawan, Muslim Tionghoa Makassar, Wawancara, 18 Oktober 2015 di Makassar.

${ }^{33}$ M. Ikhsan Tanggok, Jalan Keselamatan Melalui Jalan Konghucu (Cet. I; Jakarta: PT. Gramedia Pustaka Utama, 2000), h. 192-193.

${ }^{34}$ Lie Phie Pi, Muslim Tionghoa Makassar, Wawancara, 14 Desember 2015 di Makassar.

${ }^{35}$ Siok Tji Caang (Hj. Titian Normah), Muslimah Tionghoa Makassar, Wawancara, 26 Oktober 2015 di Makassar.
} 
berkumpul lagi bersantap bersama dan di hari Imlek mereka pun juga berkumpul meskipun di antara keluarga itu ada yang beragama Islam atau beragama Kristen. ${ }^{36}$

Fakta keberagamaan di atas menampakkan adanya sikap toleransi dalam beragama yang dimiliki oleh muslim Tionghoa. Bentuk lain dari toleransi beragama orang-orang Tionghoa ditampilkan oleh salah seorang muslim Tionghoa di Makassar. Menurutnya, toleransi beragama harus diusahakan seminimal mungkin dan tidak boleh masuk dalam wilayah yang bersentuhan akidah. Mengucapkan "selamat Hari Natal" bagi anggota keluarga yang memeluk Kristen dianggapnya melanggar komitmen akidah Islam yang diyakini kebenarannya. ${ }^{37}$

Dari data dari salah seorang informan diketahui bahwa perayaan tahun baru Imlek pernah dilakukan di pelataran salah satu mesjid Muhammad Cheng Ho di Makassar, yakni di mesjid Muhammad Cheng Ho Jalan Tun Abdul Razak poros Hertasning Baru Samata Gowa. Kegiatan tersebut tidak diiringi dengan berbagai kegiatan tradisional Tionghoa sebagaimana sering dipraktekkan warga Tionghoa pada umumnya di berbagai tempat di seluruh Indonesia. Perayaan tahun baru Imlek justru dirangkaian dengan ceramah agama yang para undangannya tidak hanya terdiri dari Tionghoa muslim, tapi juga menghadirkan warga Tionghoa non muslim. Perayaan tahun baru Imlek dengan model seperti ini dimaksudkan di samping sebagai momentum bersilaturrahmi dengan sesama muslim, khususnya sesama muslim Tionghoa, juga untuk bersosialisasi dengan Tionghoa non muslim. Selain itu, perayaan Imlek yang dilakukan di pelataran mesjid juga bertujuan mempertegas eksistensi muslim Tionghoa dengan segala potensi komunitasnya, baik potensi keanggotaan maupun potensi mobilitas sosialnya yang menjadikan mesjid Muhammad Cheng Ho sebagai pusat koordinasi pembinaan keanggotaan dan pendalaman pemahaman keislaman. Dengan demikian, pemanfaatan halaman mesjid dalam perayaan tahun baru Imlek diyakini muslim Tionghoa Makassar tidak mengganggu keislaman apalagi sampai merusak akidah Islam mereka ${ }^{38}$ Dengan kata lain, meskipun perayaan Imlek dalam ajaran agama Konghucu dan Budha dianggap bagian dari tradisi keagamaan, namun bagi

\footnotetext{
${ }^{36}$ Jhon Adam, Ketua DPW PITI Sulawesi-Selatan, Wawancara, Oktober 2015.

${ }^{37}$ Irfandi Wibisono (Oei Lian Hoa), Ketua DPD PITI Kota Makassar, Wawancara, 20 Desember 2015.

${ }^{38}$ Sulaiman Go Salam (Tjia Goam Lien), Ketua Yayasan Muhammad Cheng Ho Sulawesi Selatan, Wawancara, 20 Agustus 2015 di Makassar.
} 
muslim Tionghoa Makassar eksistensi Imlek direkonstruksi menjadi bagian dari tradisi budaya, bukan tradisi keagamaan. Rekonstruksi ini diyakini dapat mengintegrasikan eksistensi muslim Tionghoa yang memiliki identitas tersendiri dengan Islam sebagai agama yang mengakomodasi tradisi sebagai media hablun min al-nnas yang menjadi salah satu sendi kesempurnaan agama seorang muslim sejati.

Fenomena keberagamaan toleran sebagai salah satu indikator moderasi beragama yang dipraktekkan oleh muslim Tionghoa Makassar adalah fenomena pembangunan salah satu mesjid Muhammad Cheng Ho, yaitu mesjid yang terletak di jalan tun Abdul Razak Hertasning Baru. Donasi pembangunan mesjid tersebut tidak hanya berasal dari sumbangan para muslim, khususnya muslim Tionghoa, namun juga non-muslim. Diakui bahwa hal ini sangat sensitif dalam wacana keberislaman, namun muslim Tionghoa tetap memastikan bahwa harta yang diperoleh Tionghoa non muslim yang kemudian disumbangkan ke pembangunan mesjid Muhammad Cheng Ho adalah hak milik pribadi dan diperoleh dengan cara-cara yang yang halal, meskipun pemiliknya bukan muslim. Hal ini tentu beralasan dalam kajian fiqih Islam karena kehalalan rezeki seseorang tidak ditentukan oleh agamanya. Seseorang mungkin saja memiliki harta yang halal meskipun tidak beragama Islam. Demikian sebaliknya, seseorang muslim mungkin saja memiliki harta yang tidak halal meskipun dia seorang muslim. Kehalalan rezeki seseorang ditentukan oleh cara memperolehnya dan tidak ditentukan oleh agama pemiliknya. Dengan prinsip seperti ini, sumbangan Tionghoa non muslim dalam pembangunan mesjid Muhammad Cheng Ho diyakini muslim Tionghoa tidak merusak akidah Islam mereka. Apalagi partisipasi finansial Tinghoa non muslim memiliki daya perekat silaturrahmi sesama warga Tionghoa yang diharapkan menjadi jembatan turunnya hidayah Islam kepada mereka. ${ }^{39}$

Di dalam Al-Qur'an ditemukan banyak ayat yang membolehkan umat muslim menjalin hubungan dengan kelompok di luar Islam ${ }^{40}$ (QS alMumtahanah/60:8). Partisipasi mereka dalam hal ini tentu tidak dapat dijadikan alasan bagi Tionghoa non muslim untuk memasuki area mesjid karena mesjid adalah tempat sakral umat Islam yang hanya bisa dimasuki oleh mereka yang muslim. Seperti halnya dengan agama-agama lain, Islam

\footnotetext{
${ }^{39}$ Irfandi Wibisono, Ketua DPD PITI Kota Makassar, Wawancara, 20 Desember 2015 di Makassar.

${ }^{40}$ Pradana Boy, Fikih Jalan Tengah : Dialektika Hukum Islam dan Masalah-Masalah Masyarakat Modern (Cet. I; Bandung: PT. Grafindo Media Pratama, 2008), h. 216-217.
} 
memiliki area sakral termasuk mesjid dan tempat-tempat di sekitar Mekkah yang batas-batasnya telah ditetapkan oleh Nabi sendiri, dan umat non muslim tidak diperbolehkan memasukinya. ${ }^{41}$ Demikian sikap membangun kepercayaan di antara berbagai kelompok dan aliran (mutual trust) merupakan fondasi dasar dari toleransi. ${ }^{42}$

\section{e. Moderasi Keberagamaan dalam Aspek Ekonomi}

Tidak sedikit muslim Tionghoa yang juga menekuni dunia usaha, meskipun jangkauannya relatif lebih kecil dibanding Tionghoa non muslim. Ketika warga Tionghoa berkonversi ke Islam, maka prinsipprinsip bisnis Tionghoa semakin dipertajam dari aspek nilai keagamaannya. Pertama, aktivitas berdagang sebagai perwujudan dari aktivitas ibadah kepada Tuhan. ${ }^{43}$ Manifestasi keyakinan Islam dalam aktivitas usaha bisnis muslim Tionghoa, ketika mereka tidak lagi melihat bisnis itu sebagai orientasi hidup atau tujuan hidup manusia.

Kedua, kegiatan berdagang juga sebagai salah satu sarana untuk berdakwah. ${ }^{44}$ Dakwah merupakan kelanjutan risalah Nabi Muhammad saw. dan menjadi amanah bagi setiap umat Islam,baik secara individu, kelompok, organisasi ataupun lembaga, ${ }^{45}$ termasuk bagi mereka yang baru muallaf (QS al-Imran/3:104). Islam memerintahkan umatnya untuk berdakwah melalui berbagai cara (QS al-Nahl/16:125), salah satunya dengan berdagang. Beliau menjadikan perdagangan sebagai sarana dakwah melalui ketauladanan, yakni dengan menjadi pedagang yang mengedepankan kejujuran, keadilan, serta mengutamakan kualitas (QS alRahman/55:7-9, QS al-Muthaffifin/83:1-6).

\section{G. Kesimpulan}

\footnotetext{
${ }^{41}$ Seyyed Hossein Nasr, The Heart of Islam: Enduring Values For Humanity, Nurasiah Fakih Sutan Harahap (terj.), Pesan-Pesan Universal Islam Untuk Kemanusiaan (Cet.I; Bandung: PT. Mizan Pustaka, 2003), h. 62-63.

${ }^{42}$ Zuhairi Misrawi, Pandangan Muslim Moderat : Toleransi, Terorisme, dan Oase Perdamaian (Cet. I; Jakarta: PT. Kompas Media Nusantara, 2010), h. 7.

${ }^{43}$ Irfandi Wibisono (Pengusaha), Ketua DPD PITI Kota Makassar, Wawancara, 20 Desember 2015.

${ }^{44}$ Irfandi Wibisono (Pengusaha), Ketua DPD PITI Kota Makassar, Wawancara, 20 Desember 2015.

${ }^{45}$ Anwar Arifin, Dakwah Kontemporer : Sebuah Studi Komunikasi (Cet. I; Yogyakarta: Graha Ilmu, 2011), h. 227.
} 
Pengkajian Islam intensif secara mingguan senantiasa diupayakan kesinambungan pelaksanaannya oleh muslim Tionghoa Kota Makassar karena memiliki beberapa tujuan. Pertama, pembinaan pemahaman keagamaan muslim Tionghoa (anggota PITI) secara internal. Kedua, mempererat silaturahmi sesama muslim Tionghoa dan muslim nonTionghoa, termasuk juga dengan muallaf yang non-Tionghoa. Ketiga, sosialisasi eksistensi muslim Tionghoa di tengah masyarakat muslim secara luas. Keempat, mempertegas identitas dan eksistensi muslim Tionghoa di kalangan Tionghoa non-muslim.

Materi yang disampaikan dalam pengkajian Islam telah disusun penjadwalannya selama tiga bulan ke depan, sehingga dalam setahun penjadwalan dilakukan selama empat kali. Bobot materi atau tema pengkajian paling banyak kepada pemurnian akidah Islam, baik itu terkait akidah kepada Allah Swt. baik tauhid uluhiyah, rububiyah, maupun ubudiyah dan sedikit tentang pemaparan tata cara pelaksanaan ibadah ritual Islam secara teknis. Dominasi bobot materi akidah cukup beralasan karena sasaran utama pengkajian ini adalah mereka yang muallaf, terutama muallaf Tionghoa.

Hasil penelitian ini menunjukkan bahwa model keberagamaan muslim Tionghoa khususnya yang terlibat langsung dalam kegiatan pengkajian Islam intensif tergolong model keberagamaan moderat. Terdapat beberapa indikator yang dapat diajukan terkait dengan kesimpulan ini. Dalam aspek akidah Islam misalnya, muslim Tionghoa memiliki akidah Islam sebagaimana ditunjuk oleh Al-Qur'an dan hadis. Keyakinan keagamaan tradisional Tionghoa yang sangat menghormati dan memuja leluhur, tidak lagi direpresentasikan dalam bentuk penyembahan fisikal, namun penghormatan diarahkan ke dalam penghormatan etik yang memposisikan leluhur sebagai sosok yang telah banyak memberi kebaikan dalam kehidupan mereka. Dalam aspek tradisi dan budaya, warga Tionghoa yang berkonversi ke Islam tidak serta merta melepaskan keseluruhan tradisi kecinaan mereka. Identitas kecinaan mereka tetap dilestarikan selama hal itu tidak bersinggungan dengan ajaran Islam. Oleh karena itu, beberapa tradisi etnik masih mereka lakukan, dengan terlebih dahulu melepas unsur keagamaannya. 


\section{DAFTAR PUSTAKA}

Afif, Afthonul. 2010, Menjadi Indonesia: Pergulatan Identitas Tionghoa Muslim Indonesia. Yogyakarta: Parikesit Institute,

Arifin, Anwar. 2011, Dakwah Kontemporer : Sebuah Studi Komunikasi. Cet. I; Yogyakarta: Graha Ilmu,.

Al-Ashfahani, Al-Raghib. 1992, Mufradat Alfazh Al-Qur'an. Beirut: alDar al-Syamiyah.

Bahrum, Shaifuddin. 2003, Cina Peranakan Makassar : Pembauran Melalui Perkawinan Antar Budaya. Makassar: Yayasan Baruga Nusantara,.

Bertens, K. 2004, Etika. Jakarta: Gramedia Pustaka Utama.

Boy, Pradana. 2008, Fikih Jalan Tengah : Dialektika Hukum Islam dan Masalah-Masalah Masyarakat Modern. Cet. I; Bandung: PT. Grafindo Media Pratama,.

Darwis, M. 2007, Harmoni dan Disharmoni Sosial Etnis di Perkotaan : Studi Pola Interaksi Sosial Etnik Keturunan Tionghoa dengan Etnik Makassar di Kota Makassar. Disertasi Makassar, Program Pascasarjana Universitas Hasanuddin Makassar.

Echols, 2003, John M. dan Hasan Shadili. Kamus Inggris Indonesia. Jakarta: Gramedia.

Al-Fadl, Khaled Abou. 2005, The Great Theft : Wrestling Islam From The Extremists. America: Perfect Bound HarperCollins Publishers.

Huda, Samsul. "Orang Indonesia Tionghoa dan Persoalan Identitas", dalam Kontekstualita, Vol. 25, No. 1, 2010.

Lasiyo, "Etika Menurut Ajaran Confusius", dalam Basis Edisi Juli 1988.

Moleong, Lexy. J. 2001, Metode Penelitia Kualitatif . Bandung: Rosdakarya.

Nasr, Seyyed Hossein. 2003, The Heart of Islam: Enduring Values For Humanity. Nurasiah Fakih Sutan Harahap (terj.), Pesan-Pesan Universal Islam Untuk Kemanusiaan. Cet.I; Bandung: PT. Mizan Pustaka. 
Al-Qurtuby, 2006, Abu Abdillah Muhammad Ibn Ahmad Ibn Abu Bakar. al-Jami' li Ahkam Al-Qur'an. Juz XI, Cet. I; Beirut-Libanon: Muassasah al-Risalah.

Qutub, Sayyid. 1971, F̄̄ Dzilal al-Qur'an. Jilid II, Cet.; Beirut-Libanon: Dar Ihya al-Turas al-'Arabi.

Rahman, Fazlur. The major Themes of The Qur'an. Anas Mahyuddin (terj.), Tema Pokok al-Qur'an,

Ridwan, A.H. 1998, Reformasi Intelektual Islam : Pemikiran Hassan Hanafi tentang Reaktualisasi Tradisi Keilmuan Islam. Yogyakarta: ITTAQA Press.

Rosmini, 2015, Ekstremisme Keberagamaan Perspektif Al-Qur'an, Disertasi (Pascasarjana Universitas Islam Negeri Alauddin Makassar.

Shihab, M. Quraish. 2006, Tafsir al-Mishbah : Pesan, Kesan, dan Keserasian Al-Qur'an. Cet. VI; Jakarta: Lentera Hati.

Al-Syalabi, Ali Muhammad. Wasathiyyat Al-Qur'an fi al- 'Aqa'id : Arkan al-iman al-Sittah (Iskandariyyah: Dar al-iman, t.th).

Al-Syathibi, al-Muwafaqat fi Ushul al-Fiqhi, Jilid IV (Beirut: Dar alMa'rifah).

Usmani, Sa'du al-Din. Tasarrufat al-Rasul bi al-Imamah : al-Dalalat alManhajiyyah wa al-Tasyri'iyyah, Abd. Rauf Amin (terj.), Kontekstualisasi Hadis : Menguak Muatan Hukum dan Metodologi dari Realitas Sunnah Nabi. Cet. I; Makassar: Alauddin University Press, 2011.

Zaenurrafik, 2008, A. China Naga Raksasa Asia:Rahasia Sukses China Menguasai Dunia Cet. I; Yogyakarta: GARASI. 